\title{
Nerve Growth Factor Improves the Muscle Regeneration Capacity of Muscle Stem Cells in Dystrophic Muscle
}

\author{
MITRA LAVASANI, ${ }^{1,2}$ AIPING LU, ${ }^{2}$ HAIRONG PENG, ${ }^{2}{\text { JAMES CUMMINS },{ }^{2} \text { and JOHNNY HUARD }}^{1-3}$
}

\begin{abstract}
Researchers have attempted to use gene- and cell-based therapies to restore dystrophin and alleviate the muscle weakness that results from Duchenne muscular dystrophy (DMD). Our research group has isolated populations of muscle-derived stem cells (MDSCs) from the postnatal skeletal muscle of mice. In comparison with satellite cells, MDSCs display an improved transplantation capacity in dystrophic $m d x$ muscle that we attribute to their ability to undergo long-term proliferation, self-renewal, and multipotent differentiation, including differentiation toward endothelial and neuronal lineages. Here we tested whether the use of nerve growth factor (NGF) improves the transplantation efficiency of MDSCs. We used two methods of in vitro NGF stimulation: retroviral transduction of MDSCs with a CL-NGF vector and direct stimulation of MDSCs with NGF protein. Neither method of NGF treatment changed the marker profile or proliferation behavior of the MDSCs, but direct stimulation with NGF protein significantly reduced the in vitro differentiation ability of the cells. NGF stimulation also significantly enhanced the engraftment efficiency of MDSCs transplanted within the dystrophic muscle of $m d x$ mice, resulting in the regeneration of numerous dystrophin-positive muscle fibers. These findings highlight the importance of NGF as a modulatory molecule, the study of which will broaden our understanding of its biologic role in the regeneration and repair of skeletal muscle by musclederived cells.
\end{abstract}

\section{OVERVIEW SUMMARY}

Growth factors play important roles as signaling molecules throughout postnatal development, adult life, and aging. This study investigated the effect of nerve growth factor (NGF) on the regeneration of the skeletal muscle of dystrophic $(m d x)$ mice. Transplantation of muscle-derived stem cells (MDSCs) either stimulated with or genetically engineered to express NGF resulted in the regeneration of significantly more dystrophin-positive myofibers than did transplantation of control (nontreated) MDSCs. NGF did not alter the marker profile or proliferation behavior of MDSCs; however, MDSCs stimulated with NGF exhibited reduced in vitro differentiation, which may at least partially explain their improved regeneration capacity. These findings underscore the importance of NGF during skeletal muscle tissue remodeling and indicate that this molecule can improve the muscle regeneration capacity of muscle stem cells.

\section{INTRODUCTION}

D UCHENNE MUSCULAR DYSTROPHY (DMD) is a progressive muscle disorder characterized by dystrophin deficiency that results in initial necrosis of muscle fibers, which in turn leads to progressive muscle weakness (Duchenne, 1868; Hoffman et al., 1987a; Gorospe and Hoffman, 1992). Researchers have localized dystrophin in the sarcolemma of myofibers (Arahata et al., 1988; Bonilla et al., 1988; Watkins et al., 1988), where it is thought to play a role in maintaining plasma membrane integrity and stability (Hutter et al., 1991; Menke and Jockusch, 1991; Petrof et al., 1993). Because dystrophic muscle has a heightened susceptibility to structural damage and a decreased capacity to undergo self-repair, early death commonly occurs as a result of congestive cardiac and/or respiratory failure.

Despite the extensive efforts of researchers to develop an effective way to deliver dystrophin in dystrophic muscle (e.g.,

\footnotetext{
${ }^{1}$ Department of Bioengineering, University of Pittsburgh, Pittsburgh, PA 15261.

2'Growth and Development Laboratory, Children's Hospital of Pittsburgh, Pittsburgh, PA 15213.

${ }^{3}$ Department of Orthopaedic Surgery and Department of Molecular Genetics and Biochemistry, University of Pittsburgh, Pittsburgh, PA 15213.
} 
cell and gene therapy), there is no known treatment that substantially slows the course of DMD and rescues the diseased muscle tissue. Because of the unavailability of successful gene therapy, researchers have attempted to use a variety of other approaches to impede the predictable, progressive decline in muscle strength; the most successful of these approaches involves the use of steroids. Several randomized trials focused on corticosteroids (mainly prednisone and deflazacort) have shown that steroids improve muscle function and strength by prolonging ambulation and preventing scoliosis in boys with DMD (Biggar et al., 2004; Bushby et al., 2004; Yilmaz et al., 2004). Although the mechanism is not clear, corticosteroids have antiinflammatory and membrane-stabilizing effects (Alman, 2005) and act as catabolic agents, reducing muscle fiber size in the skeletal muscle of $m d x$ mice and making the fibers less susceptible to contraction-induced muscle damage (Lynch et al., 2000). However, because not all clinical trials have generated conclusive results showing the efficacy and safety of long-term steroid use, the utility of these drugs remains unknown (Lynch, 2001; Campbell and Jacob, 2003; Manzur et al., 2004).

Advances in clinical management also have significantly improved the life expectancy of DMD patients, their functional ability, and their quality of life. These advances include the use of respiratory muscle training, noninvasive ventilation (Smith et al., 1988; Bach et al., 1991), a mechanical in-exsufflator for pediatric patients (Miske et al., 2004), and low-resistance exercise and voluntary active exercises such as swimming and hydrotherapy, which increase muscle strength and endurance (for review, see Eagle, 2002). In addition, physical therapy can help relax joint contractures and early stabilization of the spine can maintain patient balance and slow the progression of respiratory compromise (Harper et al., 2004).

Like the muscles of humans with DMD, the muscles of $m d x$ mice are dystrophin deficient because of a point mutation in the dystrophin gene (Hoffman et al., 1987b); this genetic similarity makes the $m d x$ mouse an excellent genetic and biochemical model for DMD. Unlike the muscles of humans with DMD, however, the muscles of $m d x$ mice maintain active and efficient regeneration that compensates for the repeated cycles of degeneration. Although the limb skeletal muscle of $m d x$ mice continues to undergo relatively efficient regeneration regardless of the age of the animals, muscles in the diaphragms of $m d x$ mice of all ages and in the postural-tonic muscles (such as the soleus) of old mice (more than 52 weeks) exhibit many pathologic features identical to those observed in the muscle of DMD patients, including fiber atrophy; frequent splitting, necrosis, and progressive fibrosis; and severe loss of tissue compliance (Stedman et al., 1991; Pastoret and Sebille, 1993, 1995).

Although lack of dystrophin leads to progressive muscle degeneration, the evolution of DMD is likely dependent on other factors, such as insufficient expression of growth-associated proteins. After skeletal muscle damage, quiescent myogenic stem cells, which are normally embedded in the basal lamina of the muscle fibers, are activated; these cells migrate toward the damaged area, where they undergo a cycle of proliferation, fusion, and differentiation that culminates in the generation of myofibers that replace the damaged ones (Grounds, 1991). Various growth factors appear to regulate skeletal myoblast proliferation and differentiation, play a role in different stages of muscle regeneration, and enhance the healing process (Allen et al.,
1990; Florini et al., 1991; Trippel, 1997). In addition to stimulating cell proliferation, growth factors can support cell survival and regulate critical intracellular signal transduction pathways (Weiss and Schlessinger, 1998) under conditions that otherwise lead to apoptotic death.

To date, the list of growth factors known to affect the behavior of skeletal muscle cells or be expressed in skeletal muscle tissue is extensive. However, few studies have investigated the role of nerve growth factor (NGF) during skeletal muscle regeneration, and its exact mechanism of action is poorly understood. In addition to acting as a target-derived factor for developing neurons, NGF has an autocrine effect on myoblast proliferation and fusion (Rende, 1998; Ou et al., 1999; Rende et $a l ., 2000)$. Moreover, adult knockout mice expressing a neutralizing antibody against NGF display a severe dystrophy and reduced muscle mass (Capsoni et al., 2000; Ruberti et al., 2000). Evidence suggests that NGF acts by binding to the highaffinity tyrosine kinase receptor (TrkA) and the low-affinity p75-neurotrophin receptor $\left(\mathrm{p} 75^{\mathrm{NTR}}\right)$. TrkA is found in developing adult rat myoblasts (Wheeler et al., 1998) and during differentiation of muscle cells (Rende et al., 2000). NGF and $\mathrm{p} 75^{\mathrm{NTR}}$ are widely expressed in myoblasts, human myocyte cultures, and regenerating myofibers in the muscle of DMD patients (Zhao et al., 1991; Baron et al., 1994).

Previous studies in our laboratory have revealed that the delivery of human recombinant NGF protein by direct intramuscular injection improves muscle recovery (Kasemkijwattana $e t$ al., 2000; Menetrey et al., 2000). However, the efficiency of direct intramuscular injection of growth factors varies depending on the type of injury encountered and is limited by the need to maintain high-enough concentrations to achieve a therapeutic effect. In addition, the use of growth factor proteins to promote healing is severely hindered by the difficulty of ensuring their delivery to the injured site (Evans and Robbins, 1994), their short biologic half-lives (Evans and Robbins, 1994; Robbins and Ghivizzani, 1998), and the rapid clearance of these molecules from the bloodstream. For the study reported here, we used a combination of muscle-derived stem cell (MDSC)based gene therapy and direct stimulation with NGF protein to examine the effects of NGF on the proliferation and differentiation capacity of MDSCs in vitro and their regeneration efficiency in $m d x$ muscle in vivo.

\section{MATERIALS AND METHODS}

\section{Animals}

$m d x$ mice (C57BL/10SCsn DMD $\left.{ }^{\mathrm{mdx}} / \mathrm{J}\right)$ were purchased from the Jackson Laboratory (Bar Harbor, ME). All animal protocols used for these experiments were approved by the Institutional Animal Care and Use Committee of Children's Hospital of Pittsburgh (protocol 3/02).

\section{Cell isolation and culturing}

A previously described modified preplate technique (Qu-Petersen et al., 2002) was used to obtain MDSCs from normal (C57BL/6J) 3-week-old female mice. Cells were cultured at an initial density of 450 cells $/ \mathrm{cm}^{2}$ in flasks coated with collagen type I (Sigma-Aldrich, St. Louis, MO) and were maintained in 
proliferation medium (Dulbecco's modified Eagle's medium [DMEM] supplemented with $10 \%$ horse serum, $10 \%$ fetal bovine serum [FBS], and $1 \%$ penicillin-streptomycin; all GIBCO-brand reagents from Invitrogen, Carlsbad, CA) containing $0.5 \%$ chick embryo extract (Accurate Chemical, Westbury, NY). After 2 days of growth (confluency $<50 \%$ ), the cells were trypsinized, counted, and replated to generate the quantity of cells needed for each experiment.

\section{Generation of retroviral vector expressing NGF}

NGF cDNA was amplified from plasmid pSP72NGFpA (kindly provided by P. Robbins, University of Pittsburgh, Pittsburgh, PA) with primers NGF1 (agg cgg ccg ccc acc atg ctg tgc ctc aag cca gtg aaa) and NGF2 (tca aga tct tca gec tct tct tgt agc ctt cct) and $P f u$ DNA polymerase (Stratagene, La Jolla, $\mathrm{CA}$ ). The polymerase chain reaction (PCR) product was cut with restriction enzymes NotI and BglII and cloned into the same two sites of retroviral vector pCLX. The vector DNA was converted into a replication-defective retrovirus by cotransfection (by calcium phosphate precipitation) into packaging cell line GP-293 (Clontech, Palo Alto, CA) with a plasmid, pVSVG, that expressed vesicular stomatitis virus glycoprotein as the viral envelope (Peng et al., 2002). Conditioned medium containing retroviral vector was stored at $-80^{\circ} \mathrm{C}$ until use.

\section{Stimulation or retroviral transduction of MDSCs with NGF}

MDSCs were plated at 20-30\% initial confluency and either stimulated with NGF (100 ng/ml; Sigma-Aldrich) for 7 days (S-MDSCs) or retrovirally transduced (in the presence of Polybrene $[8 \mu \mathrm{g} / \mathrm{ml}]$ ) with the CL-NGF vector to express NGF (EMDSCs) at a multiplicity of infection of 5. Normal MDSCs neither stimulated nor transduced served as the control group (C-MDSCs). E-, S-, and C-MDSCs were expanded for 1 week in proliferation medium (20\% serum) at an initial density of $8 \times 10^{4}$ cells per well on collagen type I-coated 6-well plates, where they remained for $48 \mathrm{hr}$; the proliferation medium then was replaced with low-serum medium ( $2 \%$ FBS), in which the cells were cultured for an additional $24 \mathrm{hr}$. Tissue culture supernatant was collected and spun at $1200 \mathrm{rpm}$ for $5 \mathrm{~min}$ at $4^{\circ} \mathrm{C}$, and the level of functional NGF secreted by the cells in the tissue culture supernatant was measured by enzyme-linked immunosorbent assay (ELISA) (NGF $E_{\max }$ ImmunoAssay System kit; Promega, Madison, WI) performed as detailed in the manufacturer's instructions.

\section{Cell characterization by flow cytometry}

Flow cytometry was used to analyze the expression of the cell surface markers CD34 and stem cell antigen-1 (Sca-1). Cultured cells were trypsinized, spun, washed in a buffer solution made of phosphate-buffered saline (PBS) (Dulbecco phosphatebuffer salt solution $1 \times$; Mediatech, Herndon, VA) containing $0.5 \%$ bovine serum albumin (BSA; MP Biomedicals, Irvine, $\mathrm{CA}$ ) and $0.1 \%$ sodium azide (Sigma-Aldrich), and counted. After trypsinization, the cells were maintained on ice for the remainder of the procedure. The cells were then divided into aliquots and spun into a pellet. A blocking solution containing a 1:10 dilution of mouse serum (Sigma-Aldrich) in the buffer so- lution described above supplemented with $1 \mu \mathrm{l}$ of Fc block (rat anti-mouse CD16/CD32; BD Biosciences Pharmingen, San Diego, CA) was used to resuspend each pellet, and the suspensions were incubated for $10 \mathrm{~min}$ on ice. Predetermined, optimal amounts of both direct and biotin-conjugated rat antimouse monoclonal antibodies (CD34 and Sca-1) were each placed in tubes for $30 \mathrm{~min}$. Each experimental tube received fluorescein isothiocyanate (FITC)-conjugated CD34 and biotinconjugated Sca-1. A separate cell portion received equivalent amounts of isotype control antibodies. After several rinses, all fractions (including the controls) were labeled with streptavidin-allophycocyanin (APC) for $20 \mathrm{~min}$. Just before analysis, 7-amino-actinomycin D (7-AAD) was added to each tube to exclude nonviable cells from the analysis. All antibodies, including $\mathrm{APC}$ and 7-AAD, were purchased from BD Biosciences Pharmingen. At least 10,000 live cell events were analyzed by flow cytometry (FACSAria cytometer using FACSDiva software; BD Biosciences Immunocytometry Systems, Mountain View, CA).

\section{Myogenic marker expression analyzed by immunocytochemistry}

A fraction of each cell group was evaluated by immunofluorescence staining for expression of the myogenic proteins desmin and Pax-7. Analysis was performed on methanol-fixed cells that were blocked with 5\% goat serum in PBS for $1 \mathrm{hr}$. The cells were incubated for $1 \mathrm{hr}$ with the following primary antibodies: mouse IgG anti-desmin (diluted 1:250; SigmaAldrich) and mouse anti-Pax-7 (diluted 1:50; R\&D Systems, Minneapolis, MN). After being rinsed thoroughly with PBS, the cells were incubated for $30 \mathrm{~min}$ with the secondary antibody, biotinylated goat anti-mouse IgG (diluted 1:250; Vector, Burlingame, CA). To fluorescently label the antigenic binding, the cells were washed and incubated with streptavidin-Cy3 (diluted 1:500; Sigma-Aldrich) for $10 \mathrm{~min}$; nuclei then were counterstained with 4',6-diamidino-2-phenylindole (DAPI, diluted $1: 10^{4}$; Sigma-Aldrich) in PBS. All dilutions were in 5\% goat serum in PBS at room temperature. Negative control staining was performed according to an identical procedure, with omission of the primary antibody. Northern Eclipse software (version 6.0; EMPIX Imaging, Mississauga, ON, Canada) was used to quantify the percentage of myogenic cells as the ratio of cells that strongly expressed desmin or Pax-7 to the total number of nuclei in 10 randomly chosen fields at $\times 200$ magnification.

\section{Cell division and myogenic differentiation}

For analyses of population doubling time (PDT) and cellular division time (DT), cells from each group were plated at an initial density of 500 cells per well in a collagen type I-coated 12 -well plate. A novel microscope imaging system (CytoWorks; Automated Cell, Pittsburgh, PA) equipped with a $\times 20$ objective was used to acquire images at 10-min intervals over a period of 4 days. DT was measured for each treatment condition by selecting and tracking 100 cells directly from a timelapsed video record; the time lapse between cytokinesis events was recorded as the length of the cell division cycle. The average PDT was calculated by fitting an exponential trend line to several measured data points. PDT was estimated by using the software package SigmaStat 2.0 (SPSS, Chicago, IL) to per- 


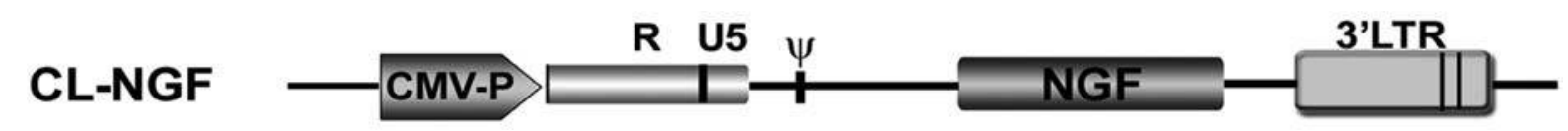

FIG. 1. Schematic of the retroviral vector expressing NGF. The vector CL-NGF carries a $3^{\prime}$ long terminal repeat (LTR), virus packing signal $(\psi)$, and human NGF cDNA driven by the cytomegalovirus promoter (CMV-P).

form nonlinear regression to generate the best fit to the curve. The fraction of daughter cells that were dividing $(\alpha)$ was calculated by measuring PDT and DT and solving the rearranged Sherley model to obtain the correlation coefficient $\left(R^{2}\right)$ for the nonlinear regression (Sherley et al., 1995; Deasy et al., 2002), a value that indicates how well the data actually fit the model (such that $0<R^{2}<1.0$ ).

Myogenic differentiation was evaluated by immunocytochemical staining for $\mathrm{MyoD}$ and fast myosin heavy chain (MyHC) expression. MyoD is a marker of early myogenic differentiation, whereas MyHC is a marker of terminal myogenic differentiation. E-, S-, and C-MDSCs were plated in collagen type I-coated 24-well plates in high-serum DMEM (described earlier). To induce differentiation, proliferation medium was replaced with differentiation medium (low serum: DMEM supplemented with $2 \%$ FBS and $1 \%$ penicillin-streptomycin). Two sets of experiments were performed to permit assessment of the rate of differentiation at multiple time points. In the first set of experiments, cells from each group were seeded at a density of 500 cells $/ \mathrm{cm}^{2}$. The cultures were shifted into differentiation medium after 3 days, and the cells were stained for MyoD and MyHC at $2,4,6$, and 8 days. In the second set of experiments, cells from each group were seeded at a density of 1000 cells $/ \mathrm{cm}^{2}$. The cultures were shifted into differentiation medium 1 day after seeding, and the cells were stained for MyoD and MyHC at 3, 5, 7, 9 , and 11 days. The differentiation medium was replaced every 2 days. Immunocytochemistry staining for MyHC was performed as described earlier for myogenic markers with monoclonal mouse anti-MyHC (diluted 1:250; Sigma-Aldrich) as the primary antibody. For immunofluorescence staining of MyoD, cultured cells were fixed with $2 \%$ paraformaldehyde in PBS containing $1 \%$ Triton X-100 and were blocked in 5\% horse serum in PBS for $1 \mathrm{hr}$. The cells then were incubated for $3 \mathrm{hr}$ with anti-MyoD monoclonal antibody clone 5.8A (diluted 1:150; BD Biosciences
Pharmingen) in the same blocking solution. The cells were exposed to a secondary biotinylated anti-mouse IgG (diluted 1:200; Vector Laboratories, Burlingame, CA) in PBS for $1 \mathrm{hr}$ and to streptavidin-Cy3 (diluted 1:500; Sigma-Aldrich) for $15 \mathrm{~min}$. Nuclei were counterstained with DAPI. All procedures were performed at room temperature. Negative control staining was performed by an identical procedure, but the primary antibody was omitted. For each group and time point, 10 randomly chosen representative fields were evaluated at $\times 200$ magnification to determine the degree of differentiation (percent ratio of MyoD- or MyHC-expressing nuclei to total number of nuclei), an indicator of differentiation efficiency.

\section{Myofiber regeneration in vivo}

A total of $(2-3) \times 10^{5} \mathrm{C}-$, E-, or S-MDSCs was injected into the gastrocnemius muscle of 6- to 8-week-old male $m d x$ mice. Mice in the E-MDSC group and their controls were immunosuppressed by subcutaneous injection of tacrolimus $\left(\mathrm{C}_{44} \mathrm{H}_{69} \mathrm{NO}_{12} \cdot \mathrm{H}_{2} \mathrm{O}\right)$, previously known as FK506 $(2.5 \mathrm{mg} / \mathrm{kg}$ mouse body weight per day; Astellas Pharma US, Deerfield, IL) beginning on the day of cell transplantation and continuing until the day of euthanization; this immunosuppression protocol is described elsewhere (Kinoshita et al., 1994). Ten to 14 days after transplantation, the gastrocnemius muscles were harvested, flash frozen in liquid nitrogen-cooled 2-methylbutane, and serially sectioned $(10 \mu \mathrm{m})$. For dystrophin staining of the cryopreserved tissue, acetone-fixed, horse serum-blocked sections were exposed to a rabbit anti-dystrophin antibody (diluted 1:1000, kindly provided by T. Partridge, Imperial College of Medicine, London, UK) for $3 \mathrm{hr}$, as previously described (Lu et al., 2003). Sections then were washed in PBS and incubated with biotinylated anti-rabbit $\mathrm{IgG}$ antibody for $1 \mathrm{hr}$. Next, the sections were washed again and incubated with streptavidin-Cy3 (diluted 1:300; Sigma-Aldrich) for
FIG. 2. Quantitative detection of the NGF protein in cell supernatant by ELISA. Two different methods of NGF stimulation were used in this study: retroviral transduction of MD$\mathrm{SCs}$ with the CL-NGF vector to induce expression of human NGF (E-MDSCs) and direct stimulation of MDSCs with NGF protein $(100 \mathrm{ng} / \mathrm{ml})$ for 7 days (S-MDSCs). For both groups, normal MDSCs that were neither stimulated nor transduced served as controls (CMDSCs). ELISA results revealed that, in comparison with S- and C-MDSCs, E-MDSCs produced a significantly higher level of NGF 3,6 , and 9 days after transduction $(n=3, * p<$ $0.05)$.

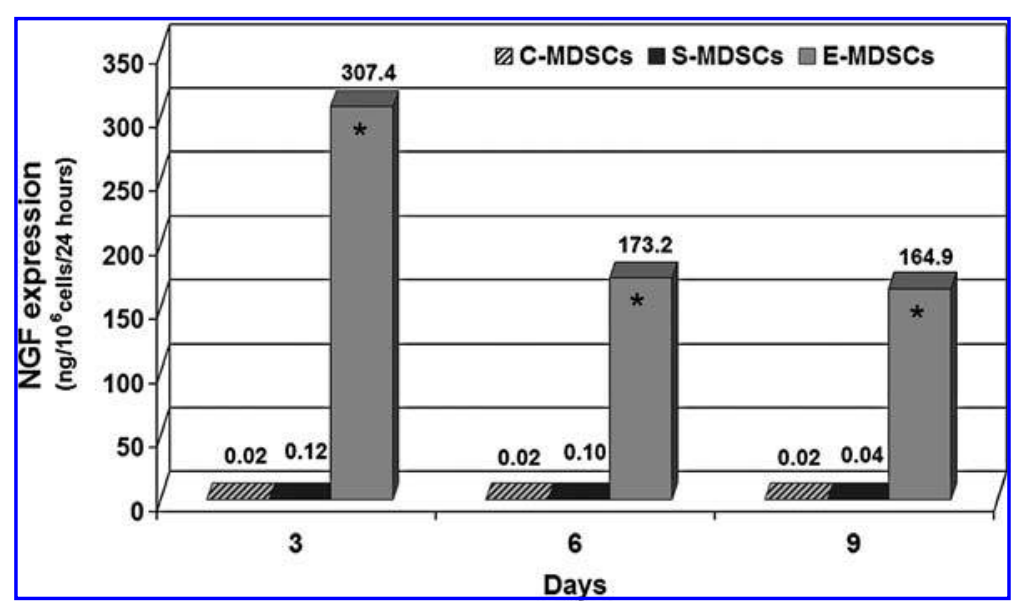


$20 \mathrm{~min}$. All incubations were at room temperature. Fluorescence microscopy was performed and digital images were acquired with a Nikon Eclipse E800 microscope equipped with a Spot digital camera and Northern Eclipse software (version 6.0; EMPIX Imaging). Muscle regeneration was assessed by manually counting the number of dystrophin-positive myofibers in an area containing the largest graft and calculating the regeneration efficiency index (RI: the number of dystrophin-positive fibers in the host muscle per $10^{5}$ donor cells) for ease of both comparison and graphical display (Jankowski et al., 2002).

\section{Myofiber analysis}

Northern Eclipse software and the same images used to calculate the RI were used to perform dimensional analysis of regenerated dystrophin-positive myofibers. Using a threshold to distinguish the immunofluorescence signal from the background signal, this software determines the area of each fiber and provides quantitative measurements of the number of pixels occupied by each individual fiber. The fiber area distribution (FAD) of 4000 individual myofibers per group was measured by determining the total number of pixels occupied by each fiber-a number that was easy to convert to square micrometers with analysis software. Hematoxylin and eosin (H\&E) staining of noninjected regions of the same grafts was used to detect the boundaries of the host $m d x$ myofibers.

\section{Statistical analysis}

Differences with $p<0.05$ were considered statistically significant. All values are given as the mean \pm standard deviation of the mean (SD). The Student $t$ test or the Mann-Whitney rank sum test (where appropriate) was used for direct comparisons between treatment and control groups. Multiple group compar- isons were made through the use of one-way analysis of variance (ANOVA) and Student-Newman-Keuls pairwise comparisons to determine the significance level. Nonparametric distributions were also detected, and comparisons were made using Kruskal-Wallis one-way ANOVA on ranks with the Tukey test for pairwise comparisons or the Dunnett test for comparing treatment groups with a single control group.

\section{RESULTS}

\section{Quantitative detection of NGF}

We used an ELISA to measure the levels of NGF secreted by MDSCs in vitro. After transduction with retroviral NGF (schematic shown in Fig. 1), genetically engineered MDSCs (EMDSCs) were able to synthesize, process, and secrete active human NGF. The level of NGF secreted by E-MDSCs reached $307.4 \pm 42.5 \mathrm{ng} / 10^{6}$ cells per $24 \mathrm{hr} 3$ days after transduction and continued to be high 6 and 9 days after transduction $\left(173.2 \pm 11.1\right.$ and $164.9 \pm 28.2 \mathrm{ng} / 10^{6}$ cells per $24 \mathrm{hr}$, respectively, $n=3, p<0.05$ ). In contrast, NGF-stimulated MDSCs (S-MDSCs) and control (nontreated) MDSCs (C-MDSCs) on average secreted NGF at barely detectable levels at the three time points $\left(0.09 \pm 0.17\right.$ and $0.02 \pm 0.37 \mathrm{ng} / 10^{6}$ cells per 24 hr, averages for S-MDSCs and C-MDSCs, respectively; Fig. 2).

\section{Proliferation kinetics}

To investigate the cellular response of MDSCs to NGF, we examined cellular division time (DT) and population doubling time (PDT). Using images acquired every $10 \mathrm{~min}$ for a period of 4 days, we measured the DT of the dividing cells ( $n=100$ cells per group) by recording the lapsed time between cytokinesis

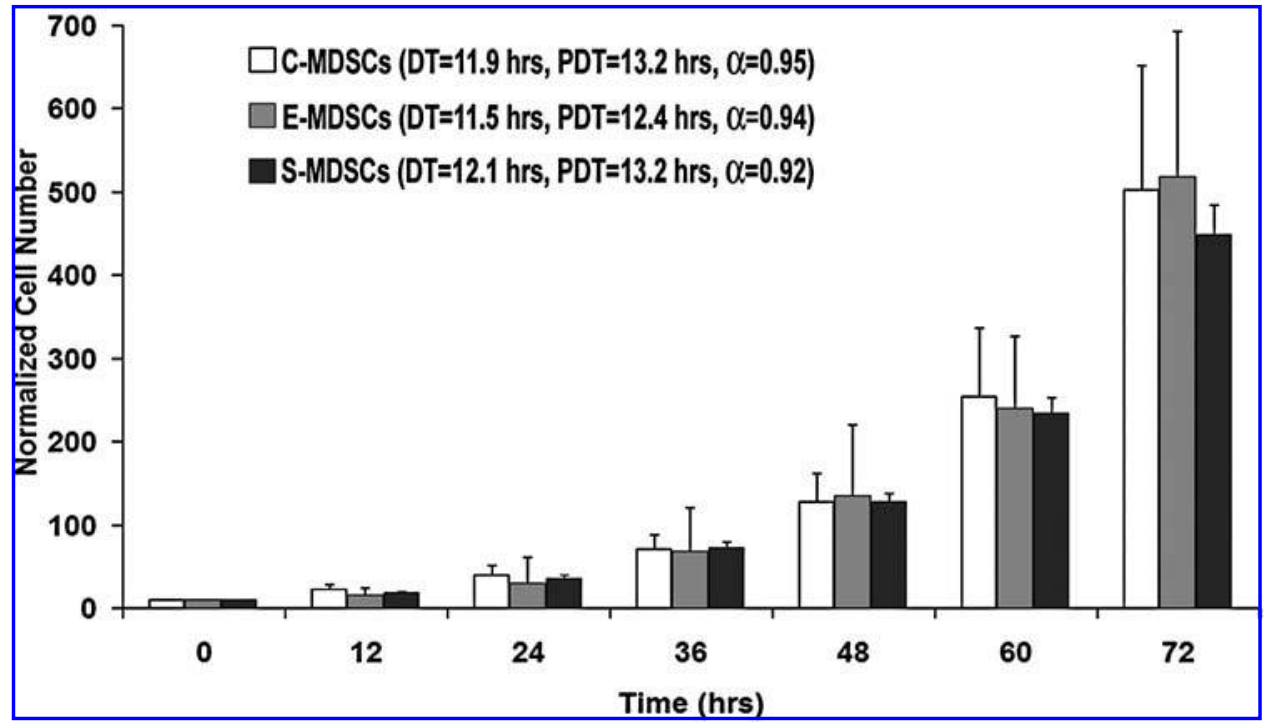

FIG. 3. Proliferation kinetics of MDSCs. Shown is the independent variable, time $(t)$, versus the dependent variable, normalized cell number. Comparison of the C-, E- , and S-MDSC groups $(n=100$ cells per group, $p=0.053)$ revealed no differences in the average cellular division time (DT) or population doubling time (PDT). We fit the experimental data sets to the model equations by using nonlinear regression to estimate the mitotic fraction $(\alpha)$ (i.e., the fraction of daughter cells that was actively dividing). The mean mitotic fraction remained relatively constant among the groups (approximately 0.94). 
events. We fit experimental data sets for C-, E-, and S-MDSCs to the Sherley model equations by using nonlinear regression with the correlation coefficient $R^{2}>0.90$ to estimate mitotic fraction $(\alpha)$ (i.e., the fraction of daughter cells that are actively dividing). Our data suggest that the average DTs (C-MDSCs, $11.9 \mathrm{hr}$; EMDSCs, $11.5 \mathrm{hr}$; and S-MDSCs, $12.1 \mathrm{hr}$ ) were not significantly different in the various groups $(p=0.053$, Kruskal-Wallis analysis on ranks) and that the PDTs of the different cell groups were also quite similar (11-13 hr). Moreover, we observed a strong association for the three groups (as indicated by $R^{2}=0.99$ ) but no difference in the estimated $\alpha$ (C-MDSCs, 0.95; E-MDSCs, 0.94; S-MDSCs, 0.92) (Fig. 3). These results indicate that neither NGF transduction nor NGF stimulation significantly altered the proliferation kinetics of MDSCs.

In vitro stem cell and myogenic marker expression profiles

Flow cytometry revealed similar expression of CD34 and Sca- 1 by C-, E-, and S-MDSCs (Fig. 4A). More than $70 \%$ of the cells in each group were positive for both stem cell markers, and we observed no significant difference between the groups (in terms of stem cell marker expression) after 2 weeks of in vitro expansion $(n=3, p=0.655)$. This marker stability suggests that NGF did not affect the stem cell marker expression of MDSCs in vitro.

We also used immunofluorescence staining to assess expression by the cells of two myogenic proteins: Pax-7 and desmin. As shown in Fig. 4B, there was no significant difference in the expression of Pax-7 by the various groups of treated and nontreated MDSCs $(n=4, p=0.148)$. Whereas E- and C-MDSCs expressed similar levels of desmin, the SMDSC group contained significantly more desmin-expressing cells $(n=4, p<0.05)$.

\section{In vitro myogenic differentiation}

After cultivating the cells under low-serum conditions and at various densities, we performed immunohistochemical staining for MyoD and fast myosin heavy chain (MyHC) expression to analyze myotube formation in the three groups (Fig. 5A-C). To

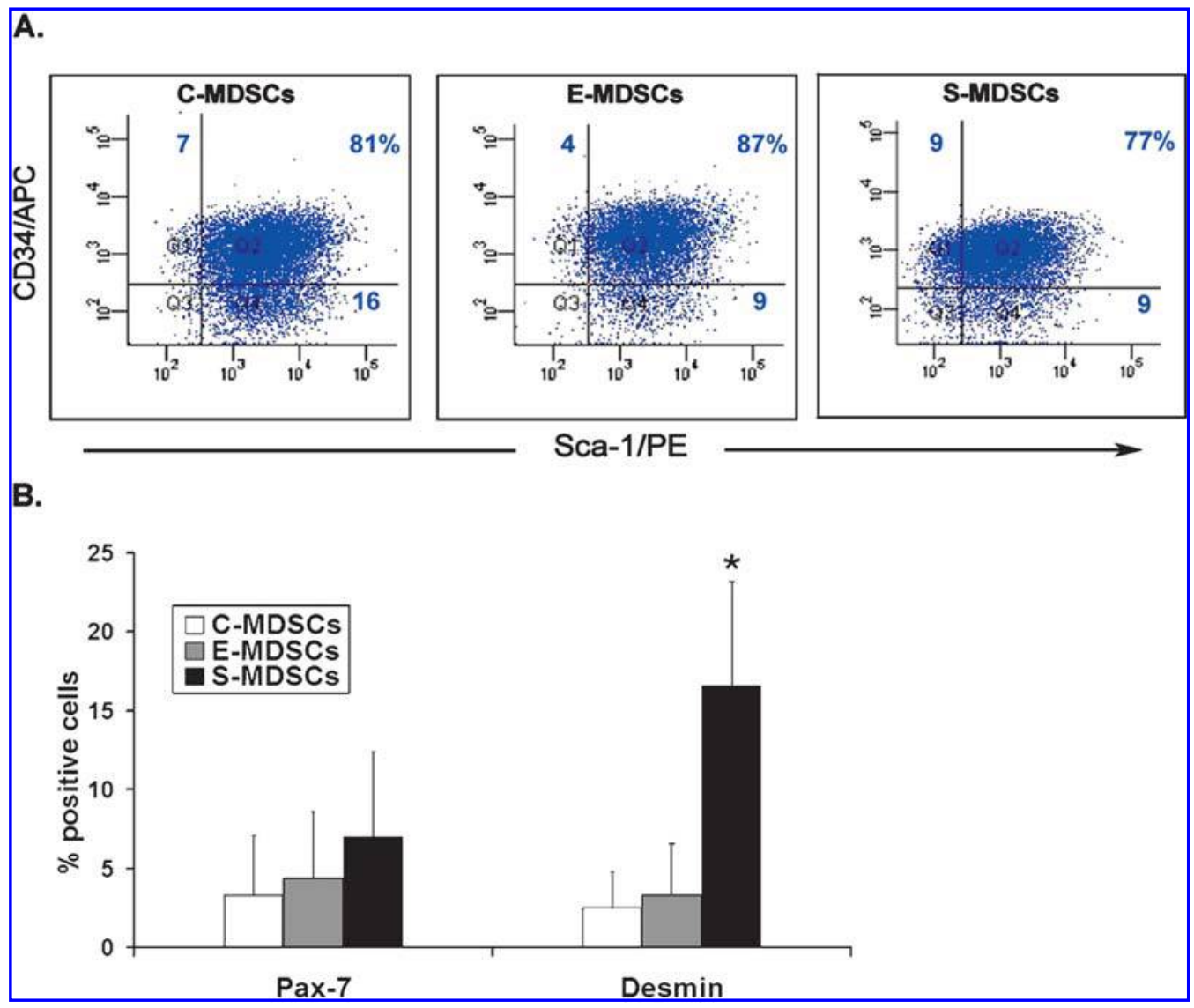

FIG. 4. Marker profile analysis of MDSCs. (A) Flow cytometry revealed high expression levels of the stem cell markers CD34 and Sca-1 $(>70 \%)$ by the control cells (C-MDSCs) and 7 days after either retroviral transduction of the cells with the CL-NGF vector (E-MDSCs) or stimulation with NGF (S-MDSCs). After 2 weeks of in vitro expansion, the groups exhibited no significant differences in marker profiles $(n=3, p=0.655)$. Data were collected by performing logarithmic amplification on 5000 cells and excluding cell debris by combining forward and side scatters and are presented as dot plots (the percentage of cells in each relevant quadrant is indicated in the upper right-hand corner). (B) A myogenic differentiation assay revealed low levels of Pax7 and desmin expression. There were no significant differences in Pax-7 expression between the treated groups and the control and no significant difference in desmin expression between E-MDSCs and C-MDSCs; however, direct stimulation of MDSCs with NGF resulted in significantly more desmin-positive cells in the S-MDSC group $(n=4, * p=0.05)$. 


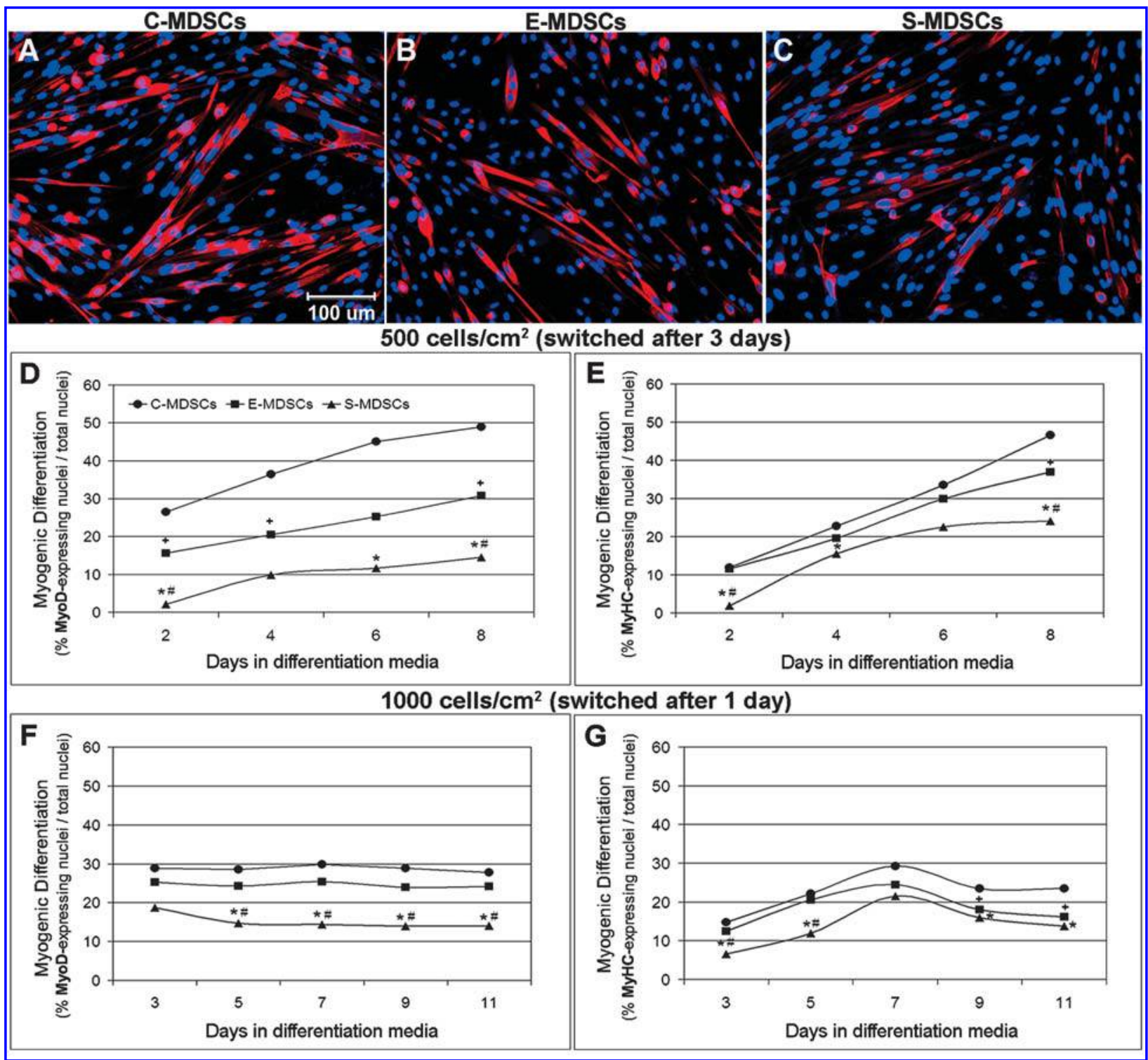

FIG. 5. Time course of myogenic differentiation in vitro. Representative images of MyHC-positive C-, E-, and S-MDSCs (Cy3; red) overlaid on nuclear counterstain (DAPI; blue) are shown (A-C). Scale bar: $100 \mu \mathrm{m}$. The degree of differentiation (percent ratio of MyoD- or MyHC-expressing nuclei to total nuclei) is indicated both for cells seeded at an initial density of $500 \mathrm{cells} / \mathrm{cm}^{2}$, switched to differentiation medium after 3 days, and stained at 2, 4, 6, and 8 days for MyoD (D) and MyHC expression (E) and for cells seeded at an initial density of 1000 cells $/ \mathrm{cm}^{2}$, switched to differentiation medium the next day, and stained at 3, 5, 7, 9, and 11 days for MyoD (F) and MyHC expression (G). Comparison of E-MDSCs (solid squares) with C-MDSCs (solid circles) revealed that the differentiation efficiency of the E-MDSCs appears to lie between the values for C-MDSCs and S-MDSCs at all time points under both experimental conditions; however, in comparison with C-MDSCs, S-MDSCs seeded at either density (solid triangles) consistently exhibited a lower degree of differentiation $\left({ }^{*} p<0.05\right.$ [S-MDSCs versus C-MDSCs], ${ }^{+} p<0.05$ [E-MDSCs versus C-MDSCs], and ${ }^{\#} p<0.05$ [E-MDSCs versus S-MDSCs], Kruskal-Wallis one-way ANOVA on ranks) (D-G). Each graph portrays results that are representative of three independent experiments.

determine the effect of cell confluency or cell differentiation, we seeded the cells at a density of either 500 or $1000 \mathrm{cells} / \mathrm{cm}^{2}$ and switched the cells to differentiation medium 3 days or 1 day after initial seeding. Under these experimental conditions, S-MDSCs consistently showed significantly lower rates of differentiation efficiency than C- and E-MDSCs, which indicates that S-MDSCs had a decreased ability to fuse and form multinucleated myotubes (Fig. 5D-G: * $p<0.05$ [S-MDSCs versus C-MD-
SCs], ${ }^{+} p<0.05$ [E-MDSCs versus C-MDSCs], and ${ }^{*} p<0.05$ [E-MDSCs versus S-MDSCs], Kruskal-Wallis one-way ANOVA on ranks). The differentiation efficiency of the E-MDSCs appears to lie between the values for C-MDSCs and S-MDSCs at all time points in both experimental conditions. These results were consistent regardless of initial cell seeding density or assay duration. Each graph portrays results that are representative of three independent experiments. 


\section{Muscle regeneration}

We evaluated the ability of the three groups of cells (C-, E-, and S-MDSCs) to regenerate dystrophic skeletal muscle by transplanting $3 \times 10^{5}$ cells from each cell group into the gastrocnemius muscles of 8 -week-old male $m d x$ mice. The dystrophin-positive grafts of E- and C-MDSCs are shown in Fig. $6 \mathrm{~A}$ and $\mathrm{B}$. The average RI of E-MDSCs was significantly larger than that of C-MDSCs $(435.6 \pm 85.5$ versus $197.5 \pm 53.8, n=$ 8 mice per group, $p<0.001$; Fig. $6 \mathrm{C})$. Differences in the size of the dystrophin-positive grafts generated by S-MDSCs and C-MDSCs were even more dramatic, as shown in Fig. 7A and $\mathrm{B}$, respectively. Our analysis revealed that the average RI of SMDSCs was 3-fold higher than that of C-MDSCs (852 \pm 203.3 versus $266.8 \pm 137.4, n=11$ mice per group, $p<0.001$; Fig. 7C). In addition, the RI of S-MDSCs was statistically higher than that of E-MDSCs $(p<0.001)$.

FAD analysis of grafts generated by the three groups of MDSCs revealed that more than 50\% of the dystrophin-positive myofibers ( $n=5000$ myofibers) in each group had areas of $0-100 \mu \mathrm{m}^{2}$; in this range, no statistically significant differences existed among the treatment groups compared with C-MDSCs ( $p=0.678$; Fig. 8). We also analyzed noninjected areas of $m d x$ muscle and found that most of the myofibers had areas greater than $1000 \mu \mathrm{m}^{2}$. These findings indicate that
C-, E-, and S-MDSCs generated new dystrophin-positive myofibers primarily through the fusion of donor cells with one another, as indicated by the small size and centronucleation of the regenerated myofibers (Fig. 8B).

\section{DISCUSSION}

Although the precise role that NGF plays in the various steps of muscle regeneration remains largely unknown, our observations indicate that NGF can improve the ability of MDSCs to regenerate the skeletal muscle of $m d x$ mice. Whereas the results of our in vitro experiments demonstrate that neither retroNGF transduction nor direct stimulation with NGF protein changes the marker profile of MDSCs or their proliferation dynamics, direct stimulation with NGF protein appears to reduce the myogenic differentiation of MDSCs in vitro.

The process of muscle regeneration in normal and dystrophic muscle depends on locally produced cytokines and growth factors (DiMario et al., 1989; Anderson et al., 1991; Clarke et al., 1993; Trippel, 1997). Skeletal muscle injuries induce a wellestablished sequence of cellular events that result in the release of growth factors that stimulate quiescent satellite cells and other muscle precursor cells to enter the cell cycle, proliferate,
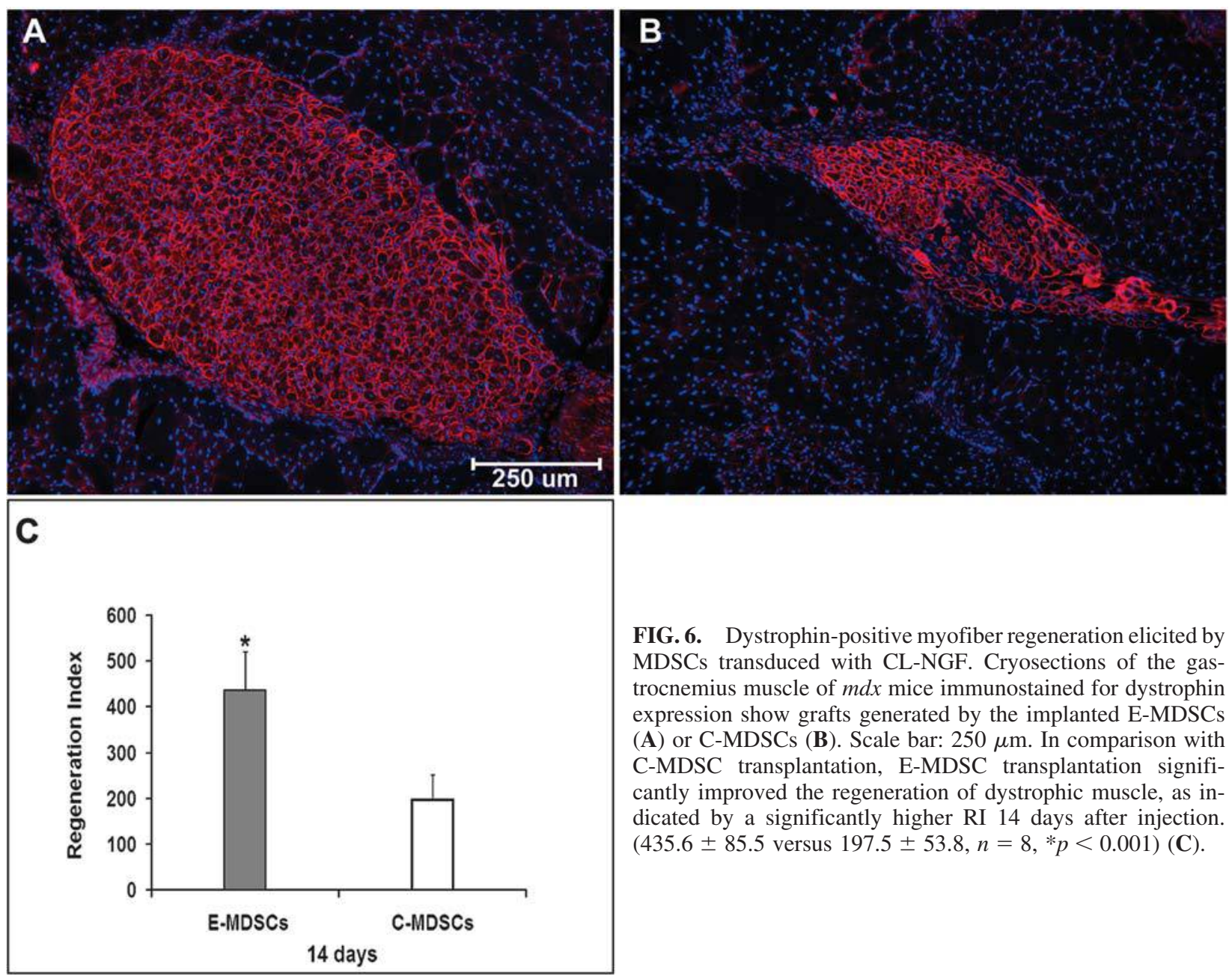

FIG. 6. Dystrophin-positive myofiber regeneration elicited by MDSCs transduced with CL-NGF. Cryosections of the gastrocnemius muscle of $m d x$ mice immunostained for dystrophin expression show grafts generated by the implanted E-MDSCs (A) or C-MDSCs (B). Scale bar: $250 \mu \mathrm{m}$. In comparison with C-MDSC transplantation, E-MDSC transplantation significantly improved the regeneration of dystrophic muscle, as indicated by a significantly higher RI 14 days after injection. $\left(435.6 \pm 85.5\right.$ versus $\left.197.5 \pm 53.8, n=8,{ }^{*} p<0.001\right)(\mathbf{C})$. 

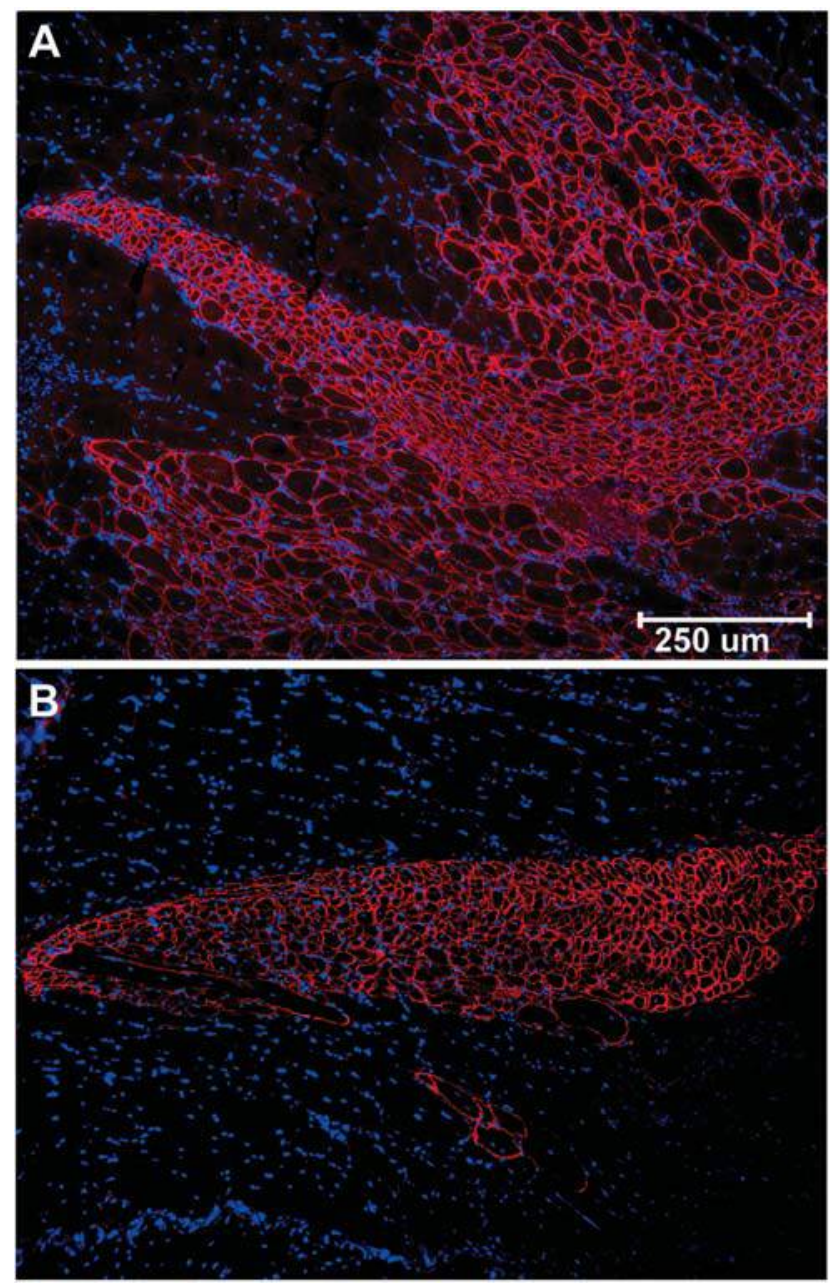

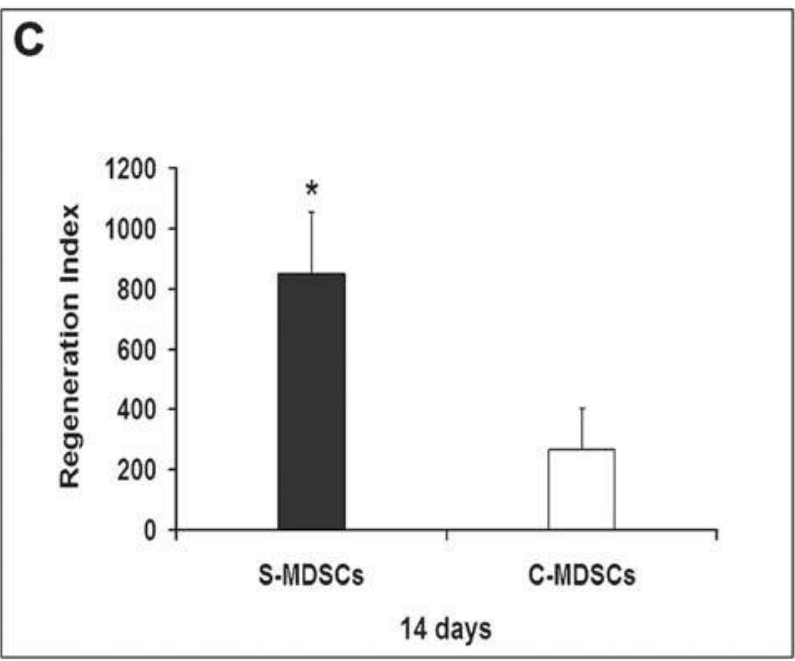

FIG. 7. Dystrophin-positive myofiber regeneration elicited by MDSCs stimulated with NGF protein. Cryosections of the gastrocnemius muscle immunostained for dystrophin expression show grafts generated by the implanted S-MDSCs (A) or C-MDSCs (B). Scale bar: $250 \mu \mathrm{m}$. In comparison with CMDSCs, S-MDSCs elicited the formation of significantly larger grafts equivalent to a 3 -fold increase in muscle regeneration 14 days after injection. The average RI of S-MDSCs was significantly higher than that of C-MDSCs $(852 \pm 203.3$ versus $266.8 \pm 137.4, n=11, * p<0.001)(\mathbf{C})$. and eventually fuse to form newly regenerated myofibers and restore muscle architecture (White and Esser, 1989; Grounds, 1991). Some studies suggest that NGF, the best characterized neurotrophic factor, plays an important role in restoring innervation in many tissues after injury. For example, NGF is integral to the survival of sensory and peripheral neurons that control contraction of smooth muscle (Kushima et al., 1992; Shitaka and Saito, 1994; Acosta et al., 2001) and axonal regeneration in skeletal muscle (McCallister et al., 2001).

A prior study performed in our laboratory has shown that MDSCs stimulated with NGF or vascular endothelial growth factor (VEGF) acquire the expression of $2^{\prime}, 3^{\prime}$-cyclic nucleotide $3^{\prime}$-phosphodiesterase (CNPase), a myelin-associated enzyme, and von Willebrand factor (vWF), an endothelial cell marker (Qu-Petersen et al., 2002), findings that indicate the potential differentiation of MDSCs toward neurogenic and endothelial lineages, respectively. These results suggest that the release of local environmental cues (1) can trigger the differentiation of muscle stem cells toward nonmyogenic lineages after transplantation of the cells into dystrophic muscle and (2) may contribute to the regeneration of functional muscle tissue by enhancing vascular and neuronal supplies.

Here we investigated whether MDSCs retrovirally transduced to express NGF display different proliferation behavior or altered myogenic differentiation in vitro and improved regeneration of dystrophic muscle in vivo. We used MDSCs rather than satellite cells because MDSCs exhibit a superior transplantation capacity in skeletal muscle and the ability to undergo multilineage differentiation (Jankowski et al., 2002; Qu-Petersen et al., 2002). The ex vivo gene transfer approach enables constant delivery of lower, more physiological doses of proteins that, if delivered by direct injection, would be quickly degraded by natural processes. Retroviral vectors infect dividing cells with high efficiency (Salvatori et al., 1993) and elicit long-term, stable expression of the gene of interest by becoming integrated within the host cell genome; such vectors are already being used in clinical settings (Anderson, 1992; Miller et al., 1992). Our results indicate that MDSCs transduced with a retrovirus vector continuously delivered high levels of NGF for up to 9 days in culture while maintaining their typical stem cell marker profile (CD34 positive and Sca-1 positive). After injection into the skeletal muscle of $m d x$ mice, E-MDSCs proliferated and differentiated to generate dystrophin-positive muscle fibers that formed a large graft as early as 14 days after injection.

The proliferation dynamics of the treated MDSCs, including PDT, DT, and $\alpha$, were similar irrespective of the treatment method (i.e., stimulation or transduction). However, S-MDSCs exhibited higher regeneration efficiency in vivo than did E-MDSCs or 


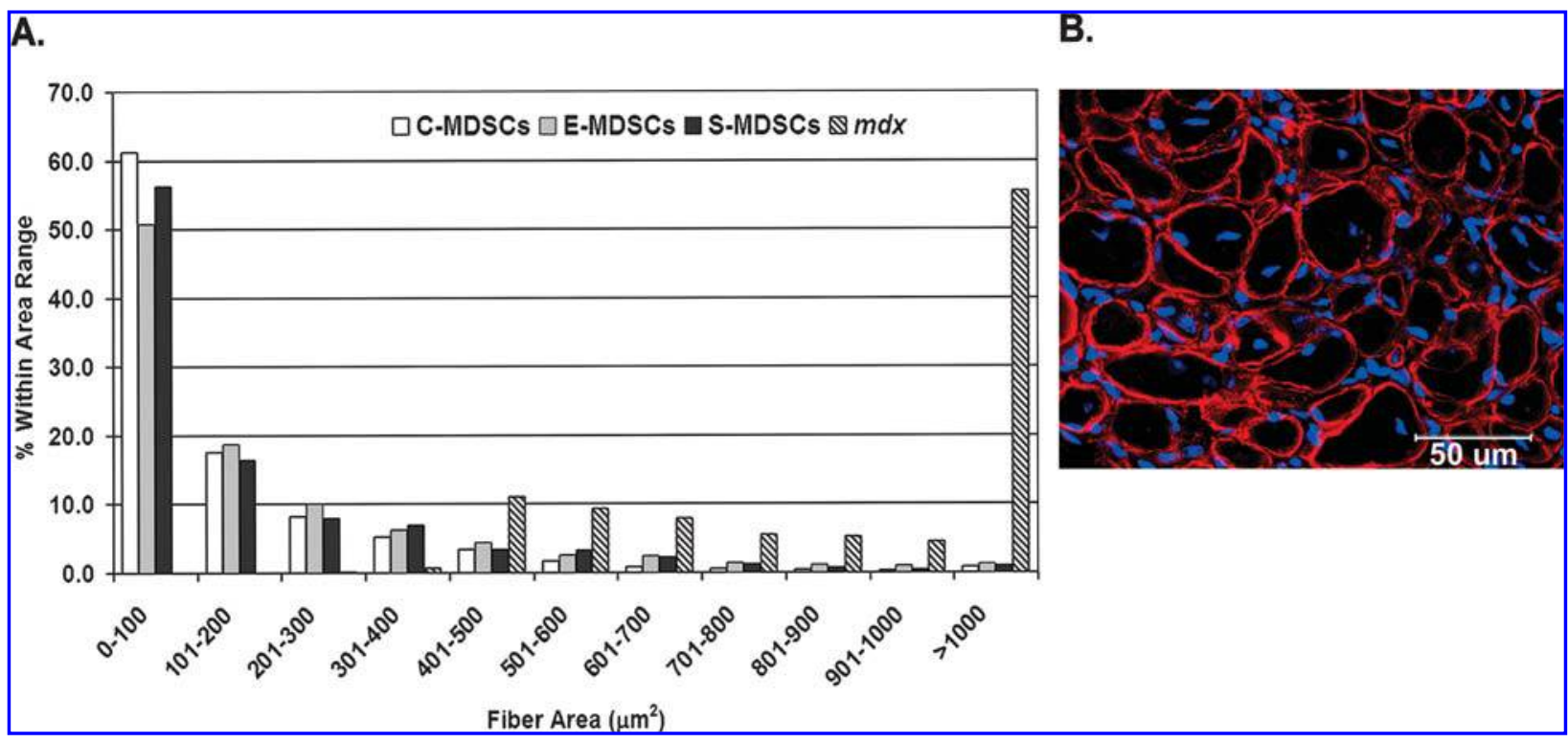

FIG. 8. Fiber area distribution (FAD) of newly generated (dystrophin-positive) and host myofibers. The overall distribution shows that most dystrophin-positive myofibers observed in the MDSC groups had areas of 0-100 $\mu \mathrm{m}^{2}$, whereas most host $m d x$ myofibers (control) had areas greater than $1000 \mu \mathrm{m}^{2}$ (A). In addition, a high-magnification image of a small portion of an EMDSC graft, which is representative of the grafts observed in all MDSC groups, shows a large number of dystrophin-positive centronucleated myofibers (B). Five thousand myofibers in treated (dystrophin-positive) and noninjected areas were analyzed in each group.

C-MDSCs. Our examination of NGF secretion by the S- and E-MDSCs in vivo revealed no differences in the immunoreactivity of the cells to NGF (data not shown). However, it is important to note that the immunopositivity exhibited by the MDSCs could be due to both NGF from other sources in the muscle and NGF secreted by the injected cells. We postulate that the enhanced muscle regeneration exhibited by S-MDSCs compared with E- and C-MDSCs in vivo might be due to the lower degree of S-MDSC differentiation. Some research suggests that muscle cells with decreased fusion characteristics have increased regeneration capacities in skeletal muscle (Jankowski et al., 2002). This could explain our observation that S-MDSCs differentiated into myotubes less effectively than did C- and EMDSCs in vitro and exhibited the greatest regeneration efficiency in vivo. The higher proliferation ability of S-MDSCs before fusion in vivo might have allowed them to remain in an undifferentiated state longer, which would result in enhanced regeneration.

We were unable to uncover a cellular mechanism that would explain the relationship between the lower expression of the myogenic differentiation markers MyoD and MyHC by S-MDSCs and their higher expression of the myogenic proliferation marker desmin. We posit that exposure to exogenous NGF myogenic differentiation conditions (low serum level) reduces differentiation but permits proliferation. S-MDSCs and E-MDSCs initially seeded at higher densities and switched to differentiation medium 3 days after seeding showed lower fusion kinetics in vitro than did similarly cultured C-MDSCs.

Reddypalli and associates (2005) reported that signaling mediated by $\mathrm{p} 75^{\mathrm{NTR}}$, the low-affinity receptor for NGF, plays an important role in normal muscle development; indeed, the ab- sence of $\mathrm{p} 75^{\mathrm{NTR}}$ in mutant mice leads to impaired muscle force. They have also found that $\mathrm{p} 75^{\mathrm{NTR}}$-mediated phosphorylation of Akt plays an important role in myoblast survival and that endogenous activation of Akt is most likely mediated by secreted NGF. The significance of the autocrine signaling by NGF is underscored by its downregulation before myoblast differentiation (Rende et al., 2000). Because Akt mediates cell survival and $\mathrm{p} 75^{\mathrm{NTR}}$ activation can promote phosphorylation of Akt, we posit that NGF activates Akt through p75 ${ }^{\mathrm{NTR}}$ in MDSCs and thus promotes the survival of the MDSCs and their transition into differentiated states. On the basis of these findings, we believe that stimulated MDSC expression of NGF at optimal levels (i.e., levels that closely mimic biologic conditions) leads to endogenous activation of Akt and subsequent autocrine signaling of NGF. Consequently, high levels of NGF expression (as exhibited by E-MDSCs) likely reflect changes such as downregulation of $\mathrm{p} 75^{\mathrm{NTR}}$ and/or the TrkA receptor for NGF that reduce overall binding affinities for NGF. The results of future experiments should facilitate elucidation of the signaling mechanisms and the link between the in vitro and in vivo settings used to study muscle regeneration.

The FAD shows that most of the individual dystrophin-positive myofibers in all the MDSC groups had areas of 0-100 $\mu \mathrm{m}^{2}$, whereas most of the host $m d x$ myofibers had areas of $>1000 \mu \mathrm{m}^{2}$. Nuclear staining with DAPI revealed that most of the small myofibers observed in the MDSC grafts were centronucleated. In combination, these results suggest that injection of C-, E-, or SMDSCs led to the formation of new dystrophin-positive myofibers via the fusion of donor cells with one another rather than the fusion of donor cells with host muscle fibers. Studies conducted by Toti and associates (2003) show that only regenerated myofibers 
in the muscles of DMD patients consistently express NGF; dystrophic myofibers or healthy myofibers do not show NGF immunoreactivity. In addition, the authors report that regenerated myofibers in muscle biopsy specimens from DMD patients are small and round, and occur mostly in clusters. These observations led them to hypothesize that, in addition to its autocrine function, NGF has a paracrine effect on neighboring regenerated myofibers. Our observations of myofibers generated by the MDSCs transplanted into the skeletal muscle of $m d x$ mice in this study, particularly E-MDSCs, suggest a similar phenomenon.

Our study results show that NGF plays an important role in enhancing muscle regeneration by MDSCs. The performance of additional research focused on NGF will substantially enhance our understanding of the mechanism underlying this effect and, in so doing, may lead to the improvement of cell and gene therapy strategies for the treatment of DMD and other muscular dystrophies.

\section{ACKNOWLEDGMENTS}

The authors thank Ryan Sauder for excellent editorial assistance with the manuscript, Marcelle Pellerin for technical assistance, and Drs. Bridget Deasy and Jonathan Pollett for participating in helpful scientific discussions. The authors also thank Dr. Terry Partridge and Dr. Paul Robbins for generously sharing the dystrophin antibody and NGF cDNA, respectively. This work was supported in part by grants to Dr. Johnny Huard from the Muscular Dystrophy Association, the National Institutes of Health (NIH, 1R01 AR49684-01), the Department of Defense (DOD, W81XWH-04-1-0003), the William F. and Jean W. Donaldson Chair at Children's Hospital of Pittsburgh, and the Henry J. Mankin Endowed Chair at the University of Pittsburgh.

\section{REFERENCES}

ACOSTA, C.G., FABREGA, A.R., MASCO, D.H., and LOPEZ, H.S. (2001). A sensory neuron subpopulation with unique sequential survival dependence on nerve growth factor and basic fibroblast growth factor during development. J. Neurosci. 21, 8873-8885.

ALLEN, J.B., MANTHEY, C.L., HAND, A.R., OHURA, K., ELLINGSWORTH, L., and WAHL, S.M. (1990). Rapid onset synovial inflammation and hyperplasia induced by transforming growth factor $\beta$. J. Exp. Med. 171, 231-247.

ALMAN, B.A. (2005). Duchenne muscular dystrophy and steroids: pharmacologic treatment in the absence of effective gene therapy. J. Pediatr. Orthop. 25, 554-556.

ANDERSON, J.E., LIU, L., and KARDAMI, E. (1991). Distinctive patterns of basic fibroblast growth factor (bFGF) distribution in degenerating and regenerating areas of dystrophic $(m d x)$ striated muscles. Dev. Biol. 147, 96-109.

ANDERSON, W.F. (1992). Human gene therapy. Science 256, 808-813.

ARAHATA, K., ISHIURA, S., ISHIGURO, T., TSUKAHARA, T., SUHARA, Y., EGUCHI, C., ISHIHARA, T., NONAKA, I., OZAWA, E., and SUGITA, H. (1988). Immunostaining of skeletal and cardiac muscle surface membrane with antibody against Duchenne muscular dystrophy peptide. Nature 333, 861-863.

BACH, J.R., CAMPAGNOLO, D.I., and HOEMAN, S. (1991). Life satisfaction of individuals with Duchenne muscular dystrophy using long-term mechanical ventilatory support. Am. J. Phys. Med. Rehabil. 70, 129-135.

BARON, P., SCARPINI, E., MEOLA, G., SANTILLI, I., CONTI, G., PLEASURE, D., and SCARLATO, G. (1994). Expression of the lowaffinity NGF receptor during human muscle development, regeneration, and in tissue culture. Muscle Nerve 17, 276-284.

BIGGAR, W.D., POLITANO, L., HARRIS, V.A., PASSAMANO, L., VAJSAR, J., ALMAN, B., PALLADINO, A., COMI, L.I., and NIGRO, G. (2004). Deflazacort in Duchenne muscular dystrophy: A comparison of two different protocols. Neuromuscul. Disord. 14, 476-482.

BONILLA, E., SAMITT, C.E., MIRANDA, A.F., HAYS, A.P., SALVIATI, G., DIMAURO, S., KUNKEL, L.M., HOFFMAN, E.P., and ROWLAND, L.P. (1988). Duchenne muscular dystrophy: Deficiency of dystrophin at the muscle cell surface. Cell 54, 447-452. BUSHBY, K., MUNTONI, F., URTIZBEREA, A., HUGHES, R., and GRIGGS, R. (2004). Report on the 124th ENMC International Workshop. Treatment of Duchenne muscular dystrophy: Defining the gold standards of management in the use of corticosteroids. April 2-4, 2004, Naarden, The Netherlands. Neuromuscul. Disord. 14, 526-534.

CAMPBELL, C., and JACOB, P. (2003). Deflazacort for the treatment of Duchenne dystrophy: A systematic review. BMC Neurol. $3,7$.

CAPSONI, S., RUBERTI, F., DI DANIEL, E., and CATTANEO, A. (2000). Muscular dystrophy in adult and aged anti-NGF transgenic mice resembles an inclusion body myopathy. J. Neurosci. Res. 59, 553-560.

CLARKE, M.S., KHAKEE, R., and MCNEIL, P.L. (1993). Loss of cytoplasmic basic fibroblast growth factor from physiologically wounded myofibers of normal and dystrophic muscle. J. Cell Sci. 106, 121-133.

DEASY, B.M., QU-PETERSEN, Z., GREENBERGER, J.S., and HUARD, J. (2002). Mechanisms of muscle stem cell expansion with cytokines. Stem Cells 20, 50-60.

DIMARIO, J., BUFFINGER, N., YAMADA, S., and STROHMAN, R.C. (1989). Fibroblast growth factor in the extracellular matrix of dystrophic $(m d x)$ mouse muscle. Science 244, 688-690.

DUCHENNE, G.B. (1868). Researches sur la paralysie musculaire pseudo-hyperophique ou paralysie myo-sclerotique. Arch. Gen. Med. 11, 179, 305, 421, 552.

EAGLE, M. (2002). Report on the muscular dystrophy campaign workshop: Exercise in neuromuscular diseases Newcastle, January 2002. Neuromuscul. Disord. 12, 975-983.

EVANS, C.H., and ROBBINS, P.D. (1994). The interleukin-1 receptor antagonist and its delivery by gene transfer. Receptor 4, 9-15.

FLORINI, J.R., EWTON, D.Z., and MAGRI, K.A. (1991). Hormones, growth factors, and myogenic differentiation. Annu. Rev. Physiol. 53, 201-216.

GOROSPE, J.R., and HOFFMAN, E.P. (1992). Duchenne muscular dystrophy. Curr. Opin. Rheumatol. 4, 794-800.

GROUNDS, M.D. (1991). Towards understanding skeletal muscle regeneration. Pathol. Res. Pract. 187, 1-22.

HARPER, C.M., AMBLER, G., and EDGE, G. (2004). The prognostic value of pre-operative predicted forced vital capacity in corrective spinal surgery for Duchenne's muscular dystrophy. Anaesthesia 59, 1160-1162.

HOFFMAN, E.P., BROWN, R.H., Jr., and KUNKEL, L.M. (1987a). Dystrophin: The protein product of the Duchenne muscular dystrophy locus. Cell 51, 919-928.

HOFFMAN, E.P., MONACO, A.P., FEENER, C.C., and KUNKEL, L.M. (1987b). Conservation of the Duchenne muscular dystrophy gene in mice and humans. Science 238, 347-350.

HUTTER, O.F., BURTON, F.L., and BOVELL, D.L. (1991). Mechanical properties of normal and $m d x$ mouse sarcolemma: bear- 
ing on function of dystrophin. J. Muscle Res. Cell Motil. 12, 585-589.

JANKOWSKI, R.J., DEASY, B.M., CAO, B., GATES, C., and HUARD, J. (2002). The role of CD34 expression and cellular fusion in the regeneration capacity of myogenic progenitor cells. J. Cell Sci. 115, 4361-4374.

KASEMKIJWATTANA, C., MENETREY, J., BOSCH, P., SOMOGYI, G., MORELAND, M.S., FU, F.H., BURANAPANITKIT, B., WATKINS, S.S., and HUARD, J. (2000). Use of growth factors to improve muscle healing after strain injury. Clin. Orthop. 370, 272-285.

KINOSHITA, I., VILQUIN, J.T., GUERETTE, B., ASSELIN, I., ROY, R., and TREMBLAY, J.P. (1994). Very efficient myoblast allotransplantation in mice under FK506 immunosuppression. Muscle Nerve 17, 1407-1415.

KUSHIMA, Y., NISHIO, C., NONOMURA, T., and HATANAKA, H. (1992). Effects of nerve growth factor and basic fibroblast growth factor on survival of cultured septal cholinergic neurons from adult rats. Brain Res. 598, 264-270.

LU, Q.L., MANN, C.J., LOU, F., BOU-GHARIOS, G., MORRIS, G.E., XUE, S.A., FLETCHER, S., PARTRIDGE, T.A., and WILTON, S.D. (2003). Functional amounts of dystrophin produced by skipping the mutated exon in the $m d x$ dystrophic mouse. Nat. Med. 9, 1009-1014.

LYNCH, G.S. (2001). Therapies for improving muscle function in neuromuscular disorders. Exerc. Sport Sci. Rev. 29, 141-148.

LYNCH, G.S., RAFAEL, J.A., CHAMBERLAIN, J.S., and FAULKNER, J.A. (2000). Contraction-induced injury to single permeabilized muscle fibers from $m d x$, transgenic $m d x$, and control mice. Am. J. Physiol. Cell Physiol. 279, C1290-C1294.

MANZUR, A.Y., KUNTZER, T., PIKE, M., and SWAN, A. (2004). Glucocorticoid corticosteroids for Duchenne muscular dystrophy. Cochrane Database Syst. Rev. 2, CD003725.

MCCALLISTER, W.V., TANG, P., SMITH, J., and TRUMBLE, T.E. (2001). Axonal regeneration stimulated by the combination of nerve growth factor and ciliary neurotrophic factor in an end-to-side model. J. Hand Surg. Am. 26, 478-488.

MENETREY, J., KASEMKIJWATTANA, C., DAY, C.S., BOSCH, P., VOGT, M., FU, F.H., MORELAND, M.S., and HUARD, J. (2000) Growth factors improve muscle healing in vivo. J. Bone Joint Surg. Br. 82, 131-137.

MENKE, A., and JOCKUSCH, H. (1991). Decreased osmotic stability of dystrophin-less muscle cells from the $m d x$ mouse. Nature $\mathbf{3 4 9}$, 69-71.

MILLER, A.R., SKOTZKO, M.J., RHOADES, K., BELLDEGRUN, A.S., TSO, C.L., KABOO, R., MCBRIDE, W.H., JACOBS, E., KOHN, D.B., and MOEN, R. (1992). Simultaneous use of two retroviral vectors in human gene marking trials: Feasibility and potential applications. Hum. Gene Ther. 3, 619-624

MISKE, L.J., HICKEY, E.M., KOLB, S.M., WEINER, D.J., and PANITCH, H.B. (2004). Use of the mechanical in-exsufflator in pediatric patients with neuromuscular disease and impaired cough. Chest $\mathbf{1 2 5}$, 1406-1412.

OU, J.Y., CHAMBERS, J., and WHEELER, E.F. (1999). Myoblasts differentiation is accompanied by expression of the NGF receptors: Effects of NGF on the proliferation and differentiation of myoblasts. In: Proceedings of the 29th Annual Meeting of the Society for Neuroscience. Abstract 94.15 .

PASTORET, C., and SEBILLE, A. (1993). Further aspects of muscular dystrophy in $m d x$ mice. Neuromuscul. Disord. 3, 471-475.

PASTORET, C., and SEBILLE, A. (1995). $m d x$ mice show progressive weakness and muscle deterioration with age. J. Neurol. Sci. 129, 97-105.

PENG, H., WRIGHT, V., USAS, A., GEARHART, B., SHEN, H.C., CUMMINS, J., and HUARD, J. (2002). Synergistic enhancement of bone formation and healing by stem cell-expressed VEGF and bone morphogenetic protein-4. J. Clin. Invest. 110, 751-759.

PETROF, B.J., STEDMAN, H.H., SHRAGER, J.B., EBY, J., SWEENEY, H.L., and KELLY, A.M. (1993). Adaptations in myosin heavy chain expression and contractile function in dystrophic mouse diaphragm. Am. J. Physiol. 265, C834-C841.

QU-PETERSEN, Z., DEASY, B., JANKOWSKI, R., IKEZAWA, M., CUMMINS, J., PRUCHNIC, R., MYTINGER, J., CAO, B., GATES, C., WERNIG, A., and HUARD, J. (2002). Identification of a novel population of muscle stem cells in mice: potential for muscle regeneration. J. Cell Biol. 157, 851-864.

REDDYPALLI, S., ROLL, K., LEE, H.K., LUNDELL, M., BAREARODRIGUEZ, E., and WHEELER, E.F. (2005). p75NTR-mediated signaling promotes the survival of myoblasts and influences muscle strength. J. Cell. Physiol. 204, 819-829.

RENDE, M. (1998). Nerve growth factor (NGF) stimulates myoblast fusion into myotubes in a rat myogenic cell line (L6): A novel autocrine role for NGF in muscle development. In: Proceedings of the 28th Annual Meeting of Society for Neuroscience. Abstract 801.10.

RENDE, M., BRIZI, E., CONNER, J., TREVES, S., CENSIER, K., PROVENZANO, C., TAGLIALATELA, G., SANNA, P.P., and DONATO, R. (2000). Nerve growth factor (NGF) influences differentiation and proliferation of myogenic cells in vitro via TrKA. Int. J. Dev. Neurosci. 18, 869-885.

ROBBINS, P.D., and GHIVIZZANI, S.C. (1998). Viral vectors for gene therapy. Pharmacol. Ther. 80, 35-47.

RUBERTI, F., CAPSONI, S., COMPARINI, A., DI DANIEL, E., FRANZOT, J., GONFLONI, S., ROSSI, G., BERARDI, N., and CATTANEO, A. (2000). Phenotypic knockout of nerve growth factor in adult transgenic mice reveals severe deficits in basal forebrain cholinergic neurons, cell death in the spleen, and skeletal muscle dystrophy. J. Neurosci. 20, 2589-2601.

SALVATORI, G., FERRARI, G., MEZZOGIORNO, A., SERVIDEI, S., COLETTA, M., TONALI, P., GIAVAZZI, R., COSSU, G., and MAVILIO, F. (1993). Retroviral vector-mediated gene transfer into human primary myogenic cells leads to expression in muscle fibers in vivo. Hum. Gene Ther. 4, 713-723.

SHERLEY, J.L., STADLER, P.B., and STADLER, J.S. (1995). A quantitative method for the analysis of mammalian cell proliferation in culture in terms of dividing and non-dividing cells. Cell Prolif. 28, 137-144.

SHITAKA, Y., and SAITO, H. (1994). The effect of basic fibroblast growth factor (bFGF) and nerve growth factor (NGF) on the survival of septal neurons transplanted into the third ventricle in rats. Jpn. J. Pharmacol. 64, 27-33.

SMITH, P.E., COAKLEY, J.H., and EDWARDS, R.H. (1988). Respiratory muscle training in Duchenne muscular dystrophy. Muscle Nerve 11, 784-785.

STEDMAN, H.H., SWEENEY, H.L., SHRAGER, J.B., MAGUIRE, H.C., PANETTIERI, R.A., PETROF, B., NARUSAWA, M., LEFEROVICH, J.M., SLADKY, J.T., and KELLY, A.M. (1991). The $m d x$ mouse diaphragm reproduces the degenerative changes of Duchenne muscular dystrophy. Nature 352, 536-539.

TOTI, P., VILLANOVA, M., VATTI, R., SCHUERFELD, K., STUMPO, M., BARBAGLI, L., MALANDRINI, A., and COSTANTINI, M. (2003). Nerve growth factor expression in human dystrophic muscles. Muscle Nerve 27, 370-373.

TRIPPEL, S.B. (1997). Growth factors as therapeutic agents. Instr. Course Lect. 46, 473-476.

WATKINS, S.C., HOFFMAN, E.P., SLAYTER, H.S., and KUNKEL, L.M. (1988). Immunoelectron microscopic localization of dystrophin in myofibres. Nature 333, 863-866.

WEISS, A., and SCHLESSINGER, J. (1998). Switching signals on or off by receptor dimerization. Cell 94, 277-280.

WHEELER, E.F., GONG, H., GRIMES, R., BENOIT, D., and 
VAZQUEZ, L. (1998). p75NTR and Trk receptors are expressed in reciprocal patterns in a wide variety of non-neural tissues during rat embryonic development, indicating independent receptor functions. J. Comp. Neurol. 391, 407-428.

WHITE, T.P., and ESSER, K.A. (1989). Satellite cell and growth factor involvement in skeletal muscle growth. Med. Sci. Sports Exerc. 21, S158-S163.

YILMAZ, O., KARADUMAN, A., and TOPALOGLU, H. (2004). Prednisolone therapy in Duchenne muscular dystrophy prolongs ambulation and prevents scoliosis. Eur. J. Neurol. 11, 541-544.

ZHAO, J., YOSHIOKA, K., MIIKE, T., KAGESHITA, T., and ARAO, T. (1991). Nerve growth factor receptor immunoreactivity on the tunica adventitia of intramuscular blood vessels in childhood muscular dystrophies. Neuromuscul. Disord. 1, 135-141.
Address reprint requests to: Dr. Johnny Huard

Growth and Development Laboratory Children's Hospital of Pittsburgh 4100 Rangos Research Center, 3460 Fifth Avenue Pittsburgh, PA 15213-2585

E-mail: jhuard@pitt.edu

Received for publication March 30, 2005; accepted after revision December 5, 2005.

Published online: January 5, 2006. 


\section{This article has been cited by:}

1. Mitra Lavasani, Seth D. Thompson, Jonathan B. Pollett, Arvydas Usas, Aiping Lu, Donna B. Stolz, Katherine A. Clark, Bin Sun, Bruno Péault, Johnny Huard. 2014. Human muscle-derived stem/progenitor cells promote functional murine peripheral nerve regeneration. Journal of Clinical Investigation 124:4, 1745-1756. [CrossRef]

2. Laura Cristina Ceafalan, Bogdan Ovidiu Popescu, Mihail Eugen Hinescu. 2014. Cellular Players in Skeletal Muscle Regeneration. BioMed Research International 2014, 1-21. [CrossRef]

3. James Tsao, Dolores A Vernet, Robert Gelfand, Istvan Kovanecz, Gaby Nolazco, Kevin W Bruhn, Nestor F Gonzalez-Cadavid. 2013. Myostatin genetic inactivation inhibits myogenesis by muscle-derived stem cells in vitro but not when implanted in the mdx mouse muscle. Stem Cell Research \& Therapy 4:1, 4. [CrossRef]

4. Minjung Song, Mitra Lavasani, Seth D Thompson, Aiping Lu, Bahar Ahani, Johnny Huard. 2013. Muscle-derived stem/ progenitor cell dysfunction in Zmpste24-deficient progeroid mice limits muscle regeneration. Stem Cell Research \& Therapy 4:2, 33. [CrossRef]

5. Keren Ettinger, Shimon Lecht, Hadar Arien-Zakay, Gadi Cohen, Shlomit Aga-Mizrachi, Nurit Yanay, H. Uri Saragovi, Hinyu Nedev, Cezary Marcinkiewicz, Yoram Nevo, Philip Lazarovici. 2012. Nerve growth factor stimulation of ERK1/2 phosphorylation requires both p75NTR and $\alpha 9 \beta 1$ integrin and confers myoprotection towards ischemia in C2C12 skeletal muscle cell model. Cellular Signalling 24:12, 2378-2388. [CrossRef]

6. Burhan Gharaibeh, Yuri Chun-Lansinger, Tanya Hagen, Sheila Jean McNeill Ingham, Vonda Wright, Freddie Fu, Johnny Huard. 2012. Biological approaches to improve skeletal muscle healing after injury and disease. Birth Defects Research Part C: Embryo Today: Reviews 96:1, 82-94. [CrossRef]

7. Burhan Gharaibeh, Bridget Deasy, Mitra Lavasani, James H. Cummins, Yong Li, Johnny HuardMusculoskeletal Tissue Injury and Repair 881-897. [CrossRef]

8. Emanuela Colombo, Stefania Romaggi, Marina Mora, Lucia Morandi, Cinthia Farina. 2011. A role for inflammatory mediators in the modulation of the neurotrophin receptor p75NTR on human muscle precursor cells. Journal of Neuroimmunology . [CrossRef]

9. Emanuela Colombo, Stefania Romaggi, Enzo Medico, Ramesh Menon, Marina Mora, Chiara Falcone, Hanns Lochmüller, Paolo Confalonieri, Renato Mantegazza, Lucia Morandi, Cinthia Farina. 2011. Human Neurotrophin Receptor p75NTR Defines Differentiation-Oriented Skeletal Muscle Precursor Cells. Journal of Neuropathology and Experimental Neurology 70:2, 133-142. [CrossRef]

10. Kunihiro Sakuma, Akihiko Yamaguchi. 2011. The Recent Understanding of the Neurotrophin's Role in Skeletal Muscle Adaptation. Journal of Biomedicine and Biotechnology 2011, 1-12. [CrossRef]

11. Dorothee Klumpp, Raymund E. Horch, Ulrich Kneser, Justus P. Beier. 2010. Engineering skeletal muscle tissue - new perspectives in vitro and in vivo. Journal of Cellular and Molecular Medicine 14:11, 2622-2629. [CrossRef]

12. Francesco Angelucci, Luca Colantoni. 2010. Facioscapulohumeral muscular dystrophy: Do neurotrophins play a role?. Muscle \& Nerve 41:1, 120-127. [CrossRef]

13. R.P. Rhoads, M.E. Fernyhough, X. Liu, D.C. McFarland, S.G. Velleman, G.J. Hausman, M.V. Dodson. 2009. Extrinsic regulation of domestic animal-derived myogenic satellite cells II. Domestic Animal Endocrinology 36:3, 111-126. [CrossRef]

14. F AMBROSIO, R FERRARI, G FITZGERALD, G CARVELL, M BONINGER, J HUARD. 2009. Functional Overloading of Dystrophic Mice Enhances Muscle-Derived Stem Cell Contribution to Muscle Contractile Capacity. Archives of Physical Medicine and Rebabilitation 90:1, 66-73. [CrossRef]

15. T NOMURA, T UEYAMA, E ASHIHARA, K TATEISHI, S ASADA, N NAKAJIMA, K ISODONO, T TAKAHASHI, H MATSUBARA, H OH. 2008. Skeletal muscle-derived progenitors capable of differentiating into cardiomyocytes proliferate through myostatin-independent TGF- $\beta$ family signaling. Biochemical and Biophysical Research Communications 365:4, 863-869. [CrossRef]

16. F FASCETTILEON, A MALERBA, L BOLDRIN, E LEONE, P BETALLI, A PASUT, G ZANON, P GAMBA, L VITIELLO, P DECOPPI. 2007. Murine Muscle Precursor Cells Survived and Integrated in a Cryoinjured Gastroesophageal Junction. Journal of Surgical Research 143:2, 253-259. [CrossRef]

17. P. Mills, J. C. Dominique, J. F. Lafrenière, M. Bouchentouf, J. P. Tremblay. 2007. A Synthetic Mechano Growth Factor E Peptide Enhances Myogenic Precursor Cell Transplantation Success. American Journal of Transplantation 7:10, 2247-2259. [CrossRef]

18. Beniamino Palmieri, Valeriana Sblendorio. 2007. Duchenne Muscular Dystrophy: An Update, Part II. Journal of Clinical Neuromuscular Disease 8:3, 122-151. [CrossRef]

19. Mitra Lavasani, Jonathan Pollett, Johnny HuardMuscle cell transplants 289-302. [CrossRef] 
20. K. A. Corsi, J. HuardMusculoskeletal tissue engineering with skeletal muscle-derived stem cells 172-186. [CrossRef]

21.J Kent Leach. 2006. Multifunctional cell-instructive materials for tissue regeneration. Regenerative Medicine 1:4, 447-455. [CrossRef] 